\title{
Research on Surface Treatment of Alloy AlCu4Mg Adhesive Bonded with Structural Single- Component Epoxy Adhesives
}

Miroslav Müller

Faculty of Engineering, Czech University of Life Sciences Prague. Czech Republic. E-mail: muller@tf.czu.cz.

Adhesive bonding technology is among the basic methods of joining. Treatment of bonded surface is seen as an essential technology for improving the strength of the bond. Improper treatment of bonded surface reduces the bonding strength and at the same time may increase the cost of manufacturing the bond. The aim of the research was to evaluate the treatment of $\mathrm{AlCu} 4 \mathrm{Mg}$ surface bonded by using single-component epoxy, which is commonly used in the transportation industry. This article describes the effect of bonded surface treatment (mechanical treatment of $\mathrm{Al}_{2} \mathrm{O}_{3}$ blasting, chemical treatment by degreasing, without modification). Evaluation of individual bonded surface modification was performed according to ČSN EN 1465. From the results of the experiments it can be concluded that all tested adhesives did not confirm the hypothesis $\mathbf{H}_{0}(\mathbf{p}<0.05)$. It follows that there is a difference in the treatment of the bonded surface. The influence of the treatment of bonded surface on adhesive bond strength and elongation of adhesive bond was statistically proved at significance level of 0.05 .

Keywords: Adhesive bond, chemical treatment, mechanical treatment, testing, without treatment

\section{Acknowledgement}

This paper has been done when solving the grant IGA TF (No.: 2015:31140/1312/3106).

\section{References}

[1] MÜLLER, M. (2011). Influence of surface integrity on bonding process. In: Research in Agricultural Engineering. Vol. 57, pp. 153-162.

[2] MÜLLER, M. (2013). Research of renovation possibility of machine tools damage by adhesive bonding technology. In: Manufacturing Technology, Vol. 13, pp. 504-509.

[3] MÜLLER, M., HERÁK, D., VALÁŠEK, P. (2013). Degradation limits of bonding technology depending on destinations Europe, Indonesia. In: Tehnicki Vjesnik- Technical Gazette, Vol. 20, pp. 571-575.

[4] PEREIRA, J.M., FERREIRA, F.V., ANTUNES, P.J., BÁRTOLO A.M. (2010). Analysis of manufacturing parameters on the shear strength of aluminium adhesive single-lap joints. In: Journal of Materials Processing Technology. Vol. 210, pp. 610-617.

[5] ELBINGA, F., ANAGREHB, N., DORNA, L., ULMANNA, E. (1999). Dry ice blastingas pretreatment of aluminum surfaces to improve the adhesive strength of aluminium bonding joints. In: International Journal of Adhesion \& Adhesives, Vol. 23 pp. 69-79.

[6] HARRIS, A.F., BEEVERS, A. (1999). The efects of grit-blasting on surface properties for adhesion. In: International Journal of Adhesion \& Adhesives, Vol. 19, pp. 445-452.

[7] BOCKENHEIMER, C., VALESKE, B., POSSART, W. (2002). Network structure in epoxy aluminium bonds after mechanical treatment. In: International Journal of Adhesion \& Adhesives, Vol. 22, pp. 349-356.

[8] LUNDER, O. et al. (2004). Effect of pre-treatment on the durability of epoxy-bonded AA6060 aluminium joints. In: International Journal of Adhesion \& Adhesives, Vol. 24, pp. 107-117.

[9] BJORGUM, A. et al. (2003). Anodising as pre-treatment for structural bonding. In: International Journal of Adhesion \& Adhesives, Vol. 23, pp. 401-412.

[10] CHEN, S. et al. (1997). Improvement of the adhesion of the resin to the metal surface by using plasma jet. In: Surface and Coating Technology, Vol. 97, pp. 378-384.

[11] MESSLER, R., W. (2004). Joining of materials and structures from pragmatic process to enabling technology. Burlington: Elsevier, 816 pp.

[12] PROLONGO, S. G. et al. (2006). Comparative study on the adhesive properties of different epoxy resins. In: International Journal of Adhesion \& Adhesives, Vol. 26, pp. 125-132.

[13] CIDLINA, J., MÜLLER, M., VÁLÁŠEK, P. (2013). Adhesive bonding technology advanced in the area of metal sheets bonding. In: The sixth international scientific conference Rural development 2013, Kaunas, Lithuania, Aleksandras Stulginskis University, 41- 46. 
[14] VALÁŠEK, P. (2014). Long-term degradation of composites exposed to liquid environments in agriculture. In. Scientia Agriculturae Bohemica, Vol. 45, pp. 187-192.

[15] MÜLLER, M. (2014). Setting of causes of adhesive bonds destruction by means of optical analysis. In. Manufacturing Technology, Vol. 14, pp. 371-375.

[16] NOVÁK, M. (2011). Surface duality hardened steels after grinding. In. Manufacturing technology, Vol. 11, pp. $55-59$.

[17] HRICOVA, J. (2014). Environmentally conscious manufacturing: the effect of metalworking fluid in high speed machining. In: Key engineering materials, Vol. 581, pp. 89-94.

[18] ŤAVODOVÁ M. (2013): The surface quality of materials after cutting by abrasive water jet evaluated by selected methods. In: Manufacturing technology, Vol. 13, pp. 236-241.

[19] ČIERNA H. ŤAVODOVA M. (2013). Using the design of experiment method to evaluate quality of cuts after cutting aluminum alloy by AWJ. In: Manufacturing technology, Vol. 13, pp. 303-307.

[20] MÜLLER, M., VALÁŠEK, P. (2013). Comparison of variables influence on adhesive bonds strength calculations. In: Manufacturing Technology, Vol. 13, pp. 205-210.

[21] MÜLLER, M. (2013). Research of liquid contaminants influence on adhesive bond strength applied in agricultural machine construction. In: Agronomy Research, Vol. 11, pp. 147-154.

[22] PAPINI, M. et al. (1994). The effect of geometry on the fracture of adhesive joint. In: International Journal of Adhesion \& Adhesives, Vol. 14, pp. 5-13.

[23] VALÁŠEK, P., MÜLLER, M. (2015). Properties of adhesives used for connecting in automotive industry. In: Acta Universitatis Agriculturae et Silviculturae Mendelianae Brunensis, Vol. 63, pp. 463-470.

[24] MÜLLER, M., RUŽBARSKÝ, J., VALÁŠEK, P. (2014). Degradation Process in Area of Connecting Metal Sheets by Adhesive. In: Applied Mechanics and Materials, Vol. 616, pp. 52-60.

[25] CIDLINA, J., MÜLLER, M., VALÁŠEK, P. (2014). Evaluation of Adhesive Bond Strength Depending on Degradation Type and Time. In: Manufacturing Technology, Vol. 14, pp. 8-12.

[26] TAMAI, Y., ARATANIC, K., (1972). Experimental study of the relation between contact angle and surface roughness. In: The Journal of Physical Chemistry. Vol. 22, pp. 3267-3271.

[27] BORSELLINO, C., DI BELLA, G., RUISI, V.F. (2009). Adhesive joining of aluminium AA6082: the effects of resin and surface treatment. In: International Journal. Adhesion \& Adhesives. Vol. 29, pp. 36-44. 